\title{
A atividade legislativa municipal \\ e sua efetividade
}

\section{Antonio Carlos Torrens ${ }^{1}$}

\begin{abstract}
Resumo: As atividades legislativas organizadas dentro do arcabouço institucional do parlamento municipal de CuritibaPR são inúmeras, impulsionadas não apenas pela necessidade de solução de demandas da população, mas são importantes elementos da conexão e das trocas que se estabelecem entre os representantes políticos, os representantes e o poder executivo. Os requerimentos, as indicações, os projetos de lei, as homenagens, cada tipo de ação parlamentar é provocada por diferentes ambições. Cada uma delas traz o seu significado e todas elas são necessárias à performance parlamentar. Por outro lado, os vereadores carecem de participação nas Audiências e Consultas Públicas e outros mecanismos de aprimoramento constitucional que possibilita a sociedade organizada opinar e alterar a discussão e encaminhamento das políticas públicas, principalmente no que se refere à construção do Orçamento Público Municipal. Os vereadores desenvolvem laços mais duradouros que trocas eleitorais em sua prática corriqueira, estabelecendo que se denomina conexão político-representativa, mas não desenvolvem participação efetiva nas grandes questões que realmente conduzem e definem a feição da administração pública municipal.
\end{abstract}

Palavras chaves: Eleição municipal. Orçamento público. Atividades legislativas. Audiências públicas. Consultas públicas.

\section{The municipal legislative activity and its effectiveness}

\begin{abstract}
Legislative activities organized within the institutional framework of the municipal of Curitiba-Pr, Parliament are numerous, driven not only by the need of attending population demands, but they are also important elements of connection and exchanges established between the political representatives, representatives and the executive power. Each type of parliamentary action is provoked by different ambitions. Each of brings its meaning and all of them necessary for parliamentary performance. On the other hand, the City councilors lack of participation in Hearings and Public Consultations and other constitutional mechanisms enable organized society to opine and change the discussion and routing of public policies, especially in the ones related to elaboration of the Municipal Public Budget. The councilors develop more lasting bonds than only electoral exchanges in their common practice, establishing what is called political representative connection, but they do not develop effective participation in the big issues that actually lead and define the politic feature of the municipal public administration.
\end{abstract}

Key words: Municipal election. Public budget. Legislative activities. Public hearings. Public consultations.

*Recebido em 30/05/2018.

*Aceito em 18/06/2018.

\footnotetext{
${ }^{1}$ Doutor em Sociologia pela Universidade Federal do Paraná. Analista das Comissões da Câmara Municipal de Curitiba desde 1994. Diretor da Escola do Legislativo da CMC - 2015/2016.
} 


\section{Introdução - O MUNICÍPIO E A ORGANIZAÇÃO POLÍTICO-ADMINISTRATIVA LOCAL:} A Câmara Municipal de Curitiba e as mudanças recentes

O objetivo desse estudo é analisar o poder legislativo municipal de Curitiba, abordagem centrada na descrição detalhada de sua organização, características próprias, competências e regras que delimitam a atuação dos representantes políticos da população do município, localizando essa narrativa no período entre os anos de 2008 e 2012, quando ocorreu mudança significativa de mando de determinado grupo político de poder municipal ${ }^{2}$.

A Câmara Municipal tem como principais funções: a formação de leis que dizem respeito à organização social e política da cidade, a fiscalização dos atos do prefeito e de todo poder executivo, através de recursos institucionais como pedidos de informação, convocação dos auxiliares do prefeito, formação de comissões parlamentares de inquérito, julgamento das contas do prefeito e fiscalização de todos os atos do poder executivo, a função fiscalizadora. Articulada a essa fiscalização a Câmara tem o poder de o poder de julgar as infrações político-administrativas do prefeito, decretar a perda do seu mandato ou de vereadores e julgar as contas da prefeitura e da própria Câmara Municipal.

A Câmara Municipal é locus privilegiado do exercício da representação popular por meio de práticas como Tribuna Livre, acordo de lideranças, audiências públicas, proporcionalidade na participação dos partidos na Mesa e Comissões. Esses elementos democráticos evidenciam a centralidade do parlamento como espelho da sociedade.

Pretendemos verificar se as mudanças no quadro eleitoral e partidário da legislatura 2013/2016 no legislativo municipal de Curitiba significaram concretamente atuação diferenciada e significativa dos vereadores na condução das políticas públicas, que são sintetizadas na Lei Orçamentária Anual (LOA), de responsabilidade exclusiva do poder executivo municipal, como são todas as leis orçamentárias ${ }^{3}$, mas que é aprovada ou não pelo legislativo.

A partir da análise das funções do legislativo, sua estrutura orgânica e o papel que desempenha como detentor da representação de um dos poderes político e público dentro do município, procuraremos desvelar como se constrói a prática legislativa, nos seus aspectos principais, que tomam o dia a dia dos parlamentares, tendo como foco a atuação deste poder em sua mais importante função,

\footnotetext{
${ }^{2}$ Grande parte da renovação da Câmara Municipal de Curitiba nas eleições de 2011 se deveu à CPI da Publicidade, que teve como consequência a deposição do Presidente da Casa, Vereador João Claudio Derosso e a não reeleição de muitos vereadores da base de apoio do seu grupo político.

${ }^{3}$ Plano Plurianual, Lei de Diretrizes Orçamentárias e Lei Orçamentária Anual.
} 
que é a de fiscalização do poder executivo na condução das políticas públicas. Essa visão abrangente do modus operandi legislativo abre espaço para verificarmos se esse poder efetivamente coloca em prática os mecanismos institucionais de acompanhamento, fiscalização e controle sobre as políticas públicas apresentadas pelo poder executivo à sociedade.

\section{Afazeres legislativos: agenda cheia}

A chamada agenda legislativa é composta de inúmeros afazeres dos agentes políticos, dos quais o recebimento do orçamento, discussão parlamentar e elaboração de emendas é apenas um deles, sem dúvida o mais importante, do ponto de vista da organização social e da escolha das prioridades das políticas públicas. Como veremos a seguir, essa prerrogativa toma um pequeno espaço entre as atividades parlamentares do dia a dia, que são inúmeras, bastante ritualizadas, de grande conteúdo simbólico, e que ocupam a maior parte do tempo do mandato ${ }^{4}$. São direcionadas tanto à produção externa quanto à administração interna, estão sujeitas ao olhar da sociedade e ao julgamento político e moral que as acompanha, e estão também sujeitas a controles interno e externo.

O controle externo mais importante, em termos políticos, é dado pela realização periódica de eleições, que possibilita a reeleição, a interrupção temporária ou o fim de um projeto político determinado.

\subsection{Da prática política à prática legislativa: as regras do jogo}

O desvelamento dos mecanismos que organizam o arcabouço institucional legislativo e que pavimentam o caminho de atuação dos dois poderes principais do município nos permite verificar que o processo legislativo não existe autonomamente, como valor em si, pois é técnica a serviço de concepções políticas, realizando fins de poder, daí sua mutabilidade no tempo e sua compreensão variada, refletindo a organização social, as formas de governo e de estado, a estrutura partidária e o sistema político. Portanto, ao apresentarmos a prática legislativa em todos os seus aspectos, queremos mostrar que a atividade e a produção legislativa possuem um roteiro intenso, necessário ao ordenamento jurídico da vida social, por suas funções - legisladora, deliberativa, fiscalizadora e julgadora, além da atividade político parlamentar em si, o debate e o encontro de tendências políticas e ideológicas representativas do corpo social. Mas, apesar de institucionalmente formalizada, a nosso

\footnotetext{
${ }^{4}$ https://www.cmc.pr.gov.br/down/RelatorioPeriodicoAtividadesParlamentares_2013.pdf
} 
ver a função fiscalizadora do poder legislativo se ressente de maior abrangência, dentro das suas possibilidades de partícipe não apenas ex post facto, mas da própria formulação das políticas públicas.

O processo de escolha dos nomes que vão compor o quadro de representantes da população do município na Câmara Municipal, significa, num primeiro momento, o coroamento de um processo social complexo, de caráter político e social, constituído pela definição da candidatura de cidadãos e cidadãs a cargos eletivos, pessoas essas com inserção em determinada comunidade ou setor social, econômico ou político; essa definição se dá, além disso, por um caminho formal e jurídico, pela regulamentação e formalidades rígidas de definição de candidaturas e regras eleitorais, iniciado em período anterior, e que tem que ser levado em consideração, sob pena de supor uma aleatoriedade que não ocorre.

A composição do quadro de candidatos eleitos indica a diversidade social, econômica, cultural e política da sociedade civil que elege os componentes do poder legislativo.

O que têm em comum um comerciante do setor de panificação, um comunicador de rádio, um geógrafo, um servidor público, uma cantora gospel, um engenheiro civil e um técnico contábil, entre outras profissões e atividades? Aparentemente fazem parte do abundante material humano social e econômico de uma grande cidade. No entanto, num determinado momento de suas vidas, há uma transfiguração dos seus papéis sociais, e os rumos que tomam a partir daí apresentam um novo contexto: ao se colocarem como candidatos em eleição municipal, sob diversas razões - por ideologia, por exposição à mídia, por uma base social ou institucional estruturada, por participação comunitária ativa, por lealdade pessoal, por desprendimento social, por vaidade, por parentesco ou por uma rede de atuação social - e obterem o número de votos necessários, tornam-se representantes parlamentares municipais, escolhidos através de eleições proporcionais periódicas. De cidadãos comuns passam a exercer o papel de intermediadores entre o Estado e a sociedade civil nas demandas por políticas públicas e nas trocas de favores políticos e sociais. Tornam-se agentes políticos, categoria social de status diferenciado por exercer função de poder e por fazer parte da direção do Estado através de eleições e de mandato.

Isso significa que haverá um grupo de pessoas que se diferenciam e fazem a conexão da sociedade civil com a esfera política, dentro de um quadro conhecido de apatia e desinteresse pela vida política e pelos negócios públicos. Os requisitos para essa diferenciação supõem a aquisição de um estoque de informações, posturas, posições e conhecimento político suficiente para a habilitação no debate e no convencimento de que essa escolha é correta para determinado grupo. Na medida da participação anterior em grupos os mais diversos de cunho social, tais como igrejas, sindicatos, associações de moradores, associações de classe, etc., a filiação partidária supõe um patamar mais elaborado de participação democrática na discussão dos rumos das tomadas de decisão dos negócios 
públicos. A efetiva participação em debates políticos organizados em partidos possibilita o conhecimento não somente de questões políticas, mas também a apreensão dos procedimentos formais da organização política, sem os quais não é possível desenvolver uma trajetória eletiva.

A participação em um partido político com afiliação de um ano no mínimo antes da candidatura, no mesmo domicílio eleitoral, é a primeira exigência para as candidaturas ${ }^{5}$. É preciso também ser aprovado pela convenção partidária, que deve estar definida por estatuto; os diretórios municipais devem convocar convenções para escolha de candidatos, com, pelo menos, três meses de antecedência às eleições. A convenção partidária deve deliberar também sobre as coligações partidárias que serão feitas; cargos que os partidos devem apresentar candidatos (cuja quantia pode ser $150 \%$ do número de vagas); se haverá candidatos às vagas majoritárias; o custo máximo de cada candidatura; sorteio dos números dos candidatos. Além disso, do número de vagas requeridas, cada partido ou coligação preencherá o mínimo de $30 \%$ e o máximo de $70 \%$ para candidaturas de cada sexo. Todos esses dados devem constar em Ata que serão apresentadas e registradas na Justiça Eleitoral e no Cartório Eleitoral. Ainda assim, todos aos atos podem ser contestados e até anulados pelos órgãos nacionais dos partidos, na medida que se verifiquem contrariedades legais aos estatutos.

Importante destacar que dos impedimentos legais para ser legislador, o principal instrumento político e jurídico, desde 1995, é a Lei da Ficha Limpa ${ }^{6}$, que é um projeto de Lei de Iniciativa Popular ${ }^{7}$ sobre a vida pregressa dos candidatos com o objetivo de tornar mais rígidos os critérios de quem não pode se candidatar, ou seja, os critérios de inelegibilidade.

Temos então cidadãos de diversos estratos sociais e econômicos e de escolaridade e profissões variadas que se projetam como candidatos de determinados partidos, com programas políticos de objetivos variados, com regras definidas e rígidas de critérios de escolha.

Na visão de Bourdieu (1983), estes representantes devem adquirir uma competência específica que é exigida assim que passam a concentrar os meios de produção política, exigindo uma preparação especial, como os saberes específicos que se produzem no trabalho político, além de uma linguagem própria e de uma retórica política. Em uma palavra, há uma iniciação, uma espécie de rito de passagem que possibilite o domínio da prática do campo político.

Para o autor, é imperativo evitar a naturalização dos "mecanismos sociais que produzem e reproduzem a separação entre os 'agentes politicamente ativos' e os 'agentes politicamente passivos',

\footnotetext{
5 Lei dos partidos políticos - lei 9.096 e 9 de setembro de 1995

6 Lei Complementar $n^{\circ} 135$ de 2010.

7 O Projeto Ficha Limpa, em todo o país, colheu mais de 1,3 milhão de assinaturas, ou seja, $1 \%$ dos eleitores brasileiros tornaram o projeto uma lei federal.
} 
e concentrar a análise da representação política dentro das determinantes econômicas e sociais da divisão do trabalho político.” (BOURDIEU, 1983, p. 162):

(...) o campo político é o lugar onde se geram, na concorrência entre os agentes que nele se acham envolvidos, produtos políticos, problemas, programas, análises, comentários, conceitos, acontecimentos, entre os quais os cidadãos comuns, reduzidos ao estatuto de 'consumidores', devem escolher, com probabilidades de mal-entendido tanto maiores quanto mais afastados estão do lugar de produção. (p. 164)

Bourdieu indica ainda que fazem parte da análise as "condições sociais da constituição social e técnica que a participação ativa na 'política' exige”, e que "a concentração do capital político nas mãos de um pequeno grupo é tanto menos contrariada e portanto tanto mais provável, quanto mais desapossados de instrumentos materiais e culturais necessários à participação ativa na política estão os simples aderentes - sobretudo o tempo livre e o capital cultural" (p. 164), distribuídos desigualmente, segundo o autor, na divisão do trabalho político: "Neste caso, como em outros, a passagem do implícito ao explícito, da impressão subjetiva à impressão objetiva, à manifestação pública num discurso ou num ato público constitui por si um ato de instituição e representa por isso uma forma de oficialização, de legitimação (...). (BOURDIEU, 1983, p. 165).

Seja qual for o enfoque, para Aurélio (2009), a representação política não deve ser tratada de maneira secundária ou instrumental na ciência política, na medida em que se trata de

(...) um conceito inscrito no próprio cerne da política enquanto tal, ou seja, da questão por excelência da sociedade vista como um conjunto de indivíduos que se atribui a si mesmo, de forma estável, uma identidade e uma vontade comuns, as quais precisam ser representadas para que o conjunto deixe de ser uma simples abstração e possa, de fato, decidir e agir enquanto todo. (AURÉLIO, 2009, p. 34)

É necessário destacar como primeiro ponto que não há praticamente aleatoriedade no processo de mudança de status social experimentado por estas pessoas, que, ao serem colocadas como candidatos, percorrem um caminho burocrático que possui características próprias, e é regido por normas políticas e jurídicas, que estão regulamentadas em extenso Código Eleitoral8. Devemos admitir, portanto, que se desenvolve certo "conhecimento" neste processo, tendo em vista a participação do candidato nas relações sociais locais, que por um lado o coloca na posição de "tradutor" de determinadas demandas, com vínculos os mais variados, dentro de uma rede de significados que dá sentido à realidade de determinado grupo social (GEERTZ, 1980), ao mesmo

\footnotetext{
${ }^{8}$ Lei no 4.737 , de 15 de julho de 1965.
} 
tempo em que corre o envolvimento em determinado partido político, com conteúdo programático, com posicionamentos públicos sobre políticas locais, regionais ou nacionais. A esta dupla relação, que Almond percebe como "um padrão particular de orientações para a ação política", um "conjunto de significados e propósitos" dentro do qual cada sistema político está embutido, é preciso acrescentar a construção das referidas "redes de significado" (GEERTZ, 1980), em que estes processos políticos de representação podem ser pensados como fenômenos "mais amplos e profundos do que as instituições formais destinadas a regulamentá-las.” (GEERTZ, p.211).

A partir daí, ocorre uma espécie de transfiguração de categorias sociais das mais diversas para apenas uma predominante, a de representante político parlamentar da população de um município. Estes escolhidos terão que obter o conhecimento das regras de direitos e deveres e a regulamentação da categoria da qual passa a fazer parte. O poder legislativo é uma instituição altamente regulamentada e ritualizada.

O eleitor, ao escolher um representante de sua escolha para titular de um mandato político, expressa uma preferência entre várias alternativas. O candidato a vereador, por sua vez, antes da eleição já se enreda numa relação jurídico-política que transcende a relação pessoal que sustenta com os eleitores de sua região, setor, bairro, Igreja, etc.

Os vereadores são, ao mesmo tempo, representantes do povo e representantes de partidos com conteúdo programático determinado, estatutos e coligações partidárias. Nessa condição, os vereadores passam a ser não apenas representantes de relações pessoais, de bairro, de organizações sociais, mas da interação entre economia/sociedade/política, dentro de um quadro de multiplicação de mecanismos de participação política da população. Essa interação está impregnada ainda de aspectos étnicos, culturais e éticos, na medida em que surgem organizações que justamente representam as diferenças étnicas, culturais e éticas. A falta de conhecimento, atenção, ou mesmo a desconsideração de todas as nuances da moderna organização social, ou o rompimento em algum momento desta interação em qualquer dos seus aspectos provoca reações as mais diversas, que muitas vezes é responsável pela derrota, pela eleição ou reeleição de determinado parlamentar.

O Estado mobiliza interesses e reúne recursos, coleta impostos e abre espaços para investimentos, distribui riquezas na educação, previdência social, empreendimentos urbanos e política social. Ganhar uma eleição significa, portanto: ocupar uma posição de prestígio e honra no aparelho de estado; fornecer atendimento aos eleitores; influir na distribuição de empregos e cargos públicos; obter participação nos negócios do estado, através da contratação de serviços, concessão de licenças e obtenção de privilégios e participar como membro dos Conselhos e Fundos Municipais da administração. 
O Poder Legislativo Municipal é o amálgama de convergências e divergências políticas, opções diferenciadas, conflito de interesses e orientações ideológicas distintas voltadas para o interesse comum, mas também com manifestações de interesses clientelistas, pessoais ou corporativos no trabalho do legislador. Este modelo de democracia representativa possui condições de operar a dinâmica de interação entre os representantes e a sociedade que os elegeu, na medida em que existam mecanismos institucionais que permitam ao representado o conhecimento, o controle e a fiscalização dos atos dos representantes eleitos.

\section{A construção das conexões políticos representativas no parlamento municipal}

\section{1. a representação política e a prática legislativa}

A representação política é o fundamento da organização, atuação, e razão de existência do Poder Legislativo, desde suas origens. A representação envolve intervenção nas grandes decisões políticas e sociais, nas conexões e inter-relações entre os partidos políticos, o Poder Executivo e nas respostas diante das expectativas e demandas do eleitorado.

Os Vereadores são aqueles que mais de perto convivem com a população, porque geralmente representam um bairro, moram em uma das ruas do Município, ou num sítio, ou na periferia. Portanto, podem conhecer as reclamações sobre problemas imediatos vividos por estas coletividades, suas aspirações e expectativas e encaminhar suas reivindicações junto aos poderes públicos, pelo conhecimento dos caminhos burocráticos e informais de encaminhamento das solicitações apresentadas.

Todo o arcabouço institucional está organizado para suprir os trabalhos legislativos nas suas funções, fazer leis, atender demandas da sociedade, fiscalizar a vida pública e a atuação do Poder Executivo.

Queremos centrar a investigação na ação legislativa que é justamente a atividade legal e cotidiana da prática parlamentar: os projetos de lei, os requerimentos, as indicações e as emendas ao orçamento. Os resultados dessa atividade são incertos quanto à sua eficácia, no entanto ocupam a maior parte do tempo de mandato, e acabam também sendo os principais canais de mediação entre os vereadores e a população, os outros vereadores e o poder executivo. Não há garantias institucionais de que os requerimentos, os projetos de lei, as indicações e as emendas orçamentárias tenham accountability para aferir a concretização das demandas públicas ao legislativo. 


\subsection{A formação da "conexão eleitoral": a construção da ação parlamentar}

Nosso objetivo neste capítulo é analisar a atividade legislativa, do ponto de vista da articulação entre os vereadores, a população e o poder executivo, no estabelecimento do que se considera como uma função legítima de representação política, referente à produção de projetos de lei, indicações, requerimentos e emendas parlamentares, notadamente as que modificam o orçamento público.

Optamos por quatro tipos de ação legislativa - Indicação, Requerimento, Projeto de Lei e Emendas ao Orçamento.

Ao Poder Legislativo cabem duas funções principais, que são legislar e fiscalizar o Poder Executivo. Quanto à fiscalização, é exercida constantemente, seja por pedidos de informação ao executivo ou nos casos mais extremos de comissões parlamentares de inquérito ou sustação das contas do prefeito. A eficácia desses procedimentos é variável, podendo trazer resultados efetivos ou serem inócuas.

Queremos demonstrar que a produção de leis é apenas um dos aspectos da atividade parlamentar, cujos membros estão mais sintonizados com os eleitores na articulação com os pedidos pontuais, através de requerimentos ao Executivo e diversos órgãos da administração e com os pedidos de informações ou indicações ao Prefeito. As emendas ao orçamento constituem importante elo com o eleitorado, que busca no legislativo esse papel de mediador de demandas das mais variadas e que não são supridas pelos canais rotineiros da administração.

\subsubsection{Indicações}

O primeiro tipo de ação parlamentar na câmara municipal que veremos é a Indicação. Temos dois tipos de Indicação: a primeira é que sugere ao poder executivo ou a qualquer órgão da administração pública uma ação que lhes cabe, e não é possível apresentar no legislativo.

Os projetos de lei que apresentam vício de iniciativa e não podem ser tratados pelo legislativo transformam-se em sugestões ao executivo para que este viabilize a questão em forma de projeto. $\mathrm{Na}$ medida em que são colocações de maior complexidade, como podemos verificar, exigem estudo prévio, alterações de grande porte e envolvimento de pessoal especializado para efetivação de algumas propostas. São medidas de inclusão social, educativas, de alterações estruturais no arcabouço municipal. Não são pedidos pontuais mas sugestões que podem ou não ser acatadas pelo executivo, mas possibilitam ao vereador interferir em demandas de maior volume, a pedido de entidades representativas ou setores organizados. Neste caso a conexão se dá somente entre o representante 
político e a população interessada. É uma relação que não tem necessariamente efetividade, não há obrigatoriedade de atendimento ou resolução por parte do poder executivo.

Os prêmios e homenagens são organizados pela instituição Câmara Municipal e são a outra vertente das Indicações. Retratam o simbólico nas relações engendradas entre os representantes políticos e o eleitorado, e com evidente intenção de ampliar este leque, ao possibilitar que a homenagem tenha retorno em forma de gratidão ou reconhecimento político pelo valor público de pessoas que se destacam em alguma área. É um elemento de importância simbólica e eleitoral, e envolve muitos setores sociais, econômicos e profissionais da população: entidades não governamentais, atividades profissionais, educação e cultura, serviço público, pessoas jurídicas de direito privado, esporte, cultura e divulgação, religião, mulheres, ecologia e ambientalismo.

São exemplos de prêmios e homenagens:

VULTO EMÉRITO Lei no 2.255/63 - Lei no 6.929/86

(Pessoas nascidas em Curitiba)

Concedido às pessoas que tenham prestado relevantes serviços à comunidade curitibana.

CIDADÃO HONORÁRIO Resol. n ${ }^{\circ}$ 04/78

(Pessoas nascidas fora de Curitiba)

Concedido às pessoas que tenham prestado relevantes serviços à comunidade curitibana.

PROFISSIONAL DO ANO - Lei no 9.622/99 - Lei no 14.302/2013

\section{CONSAGRAÇÃO PÚBLICA MUNICIPAL - Lei $\mathrm{n}^{\circ}$ 6.710/85}

Prêmio concedido às pessoas jurídicas de Direito Privado que se destacaram, anualmente, por relevantes serviços prestados à comunidade.

\subsubsection{Emendas}

São propostas de alteração de qualquer texto que se encontra em tramitação na Câmara Municipal. Somente poderá ser feita por vereador, Mesa ou Comissões. Podem suprimir, modificar, substituir ou acrescentar texto ou proposta em qualquer parte da proposição.

\subsubsection{Projetos}

São todas as propostas normativas submetidas à apreciação do legislativo. Podem ser de efeito interno à Câmara (resoluções), com efeito externo (decretos), de lei ordinária (o tipo mais usual), de lei complementar (que complementa leis já existentes) e de emendas à Lei Orgânica, que são especiais e exigem quorum diferenciado. 
REQUERIMENTOS - Principal meio de comunicação do Vereador com a população, na medida em que qualquer pedido feito ao Vereador pode ser traduzido em forma de requerimento, seja qual for sua efetividade. Representa na verdade uma atenção ao eleitor nas demandas mais pontuais e específicas (poda de árvores, pavimentação de rua) dirigida ao Executivo ou a outros órgãos municipais. Ao mesmo tempo é a atividade mais corriqueira da Câmara Municipal, e a que mais exige conhecimento de detalhes burocráticos para sua consecução, na medida em que existem muitos tipos de requerimentos, todos dirigidos à Mesa ou ao Presidente, mas com grande variedade de formas de competência: podem ser apreciados pelo Presidente, pela Mesa, pelo Plenário; podem ser verbais ou escritos; podem sofrer discussão ou não. O conhecimento legislativo sobre os requerimentos possibilita maior desenvoltura e desenvolvimento de habilidade da prática parlamentar.

\section{O Orçamento Público Municipal e o Poder Legislativo}

\subsection{Introdução}

O orçamento público é o mecanismo institucional que o Estado utiliza para atender as demandas sociais e alcançar sua finalidade de promoção do bem comum, através de ações planejadas de canalização de recursos para o financiamento de políticas sociais que traduzam seus objetivos fundamentais. Através de mecanismos de gestão dos recursos de arrecadação e tributação, organizamse projetos, programas e planejamento, que embasarão as atividades estatais num determinado período, em todas as instâncias, federal, estadual e municipal. Atualmente, desenvolveram-se mecanismos de acompanhamento e controle do orçamento público, tanto por parte da população, como por parte de órgãos responsáveis pelo controle institucional da destinação dos recursos públicos arrecadados para fins do Estado.

Temos desta maneira, por um lado, o controle institucional exercido pelos diversos órgãos cuja competência legal é a fiscalização da aplicação dos recursos públicos: Controladoria-Geral da União; Tribunais de Contas da União, Estados e Municípios; Ministério Público Federal, Ministério Público Estadual, Assembleias Legislativas, Câmaras de Vereadores e o Poder Judiciário. Por outro, há o alargamento da possibilidade de participação da sociedade organizada na elaboração e acompanhamento da gestão orçamentária: audiências públicas, portais de transparência, consultas públicas. Conforme a Constituição Federal:

Art. 31. A fiscalização do Município será exercida pelo Poder Legislativo Municipal, mediante controle externo, e pelos sistemas de controle interno do Poder Executivo Municipal, na forma da lei. 
$\S 1^{\circ}$ - O controle externo da Câmara Municipal será exercido com o auxílio dos Tribunais de Contas dos Estados ou do Município, ou dos Conselhos ou Tribunais de Contas dos Municípios, onde houver.

Formalmente, cabe aos vereadores fiscalizar e controlar as contas públicas, acompanhar a execução do orçamento do município e comprovar a legitimidade e legalidade dos atos do poder executivo.

Nosso objetivo nesse capítulo é analisar o papel do poder legislativo na configuração, acompanhamento e fiscalização da principal atividade do poder executivo no município de Curitiba, isto é, o mecanismo de organização das políticas públicas que é o orçamento, ou mais precisamente a Lei Orçamentária Municipal em período recente, em que ocorreu mudança de legislatura (2008 2012).

Em nossa visão, ao legislativo cabe papel limitado neste processo, primeiramente pelas restrições constitucionais de exclusividade do poder executivo na proposição e pela precariedade de fiscalização do parlamento na consequente execução orçamentária; além disso, são inúmeras as restrições na elaboração de emendas parlamentares ao orçamento. Ainda que seja obrigatória a aprovação do orçamento pelo legislativo, o que em tese significaria poder de barganha e alterações significativas em seu conteúdo pela representatividade do legislativo frente a população durante a discussão do mesmo, este poder se restringe à alocação de emendas parlamentares cujos gastos "não são demasiadamente fragmentados e não há indicações de que estejam em desacordo com as prioridades estabelecidas pelo Executivo.” (FIGUEIREDO \& LIMONGI, 2002, p.330)

Para esses autores,

O Legislativo brasileiro é organizado de forma centralizada. Para nos atermos apenas às questões relativas à matéria orçamentária, a Constituição, o quadro legal vigente e as próprias regras internas ao Poder Legislativo limitam o raio de ação possível da participação do Legislativo na definição do orçamento. $\mathrm{O}$ arcabouço institucional em vigor provê poucos recursos e pequenas possibilidades para que os legisladores venham a influenciar individualmente nos resultados da alocação de recursos. (p.333)

O que pretendemos elucidar neste capítulo é a capacidade de participação e fiscalização do Poder Legislativo na organização, elaboração e execução do orçamento, em suas várias etapas. Pretendemos demonstrar que o Parlamento somente participa realmente deste processo em dois momentos: primeiramente na entrega do Orçamento à Câmara Municipal para apreciação pela Comissão de Economia, Finanças e Fiscalização e votação em Plenário; e num segundo momento, de 
elaboração e aprovação das Emendas Parlamentares, o que lhe confere papel secundário na condução das políticas públicas.

\subsection{Orçamento Público: instrumento para gestão de recursos}

O Poder Executivo tem a prerrogativa constitucional exclusiva de elaboração de toda legislação relacionada às matérias orçamentárias: Plano Plurianual, Lei de Diretrizes Orçamentárias e Lei Orçamentária Anual.

O Orçamento da prefeitura de Curitiba pode ser enquadrado no tipo Orçamento Programa (ROCHA, 2010 p. 2):

O Orçamento Programa é um instrumento de planejamento que permite identificar os programas, os projetos e as atividades que o Governo pretende realizar, além de estabelecer os objetivos, as metas, os custos e os resultados esperados e oferecer maior transparências nos gastos públicos.

O orçamento público é o instrumento de gestão do Estado para administrar as demandas sociais de educação, saneamento, habitação, transporte e segurança, entre outras, seja na federação, nos estados ou nos municípios. O objetivo fundamental da execução do orçamento público é a promoção do bem comum.

A partir da constituição de 88 , acrescentou-se ao controle institucional:

1. A participação dos cidadãos e da sociedade organizada, no sentido de aumentar o monitoramento das ações governamentais e fiscalizar a destinação do dinheiro público.

2. A fixação de normas gerais de finanças públicas, com a criação dos instrumentos atuais de planejamento e orçamento: PPA - Plano Plurianual (organiza a atuação do Estado para um período de quatro anos), LDO - Lei de Diretrizes Orçamentárias (instrumento por meio do qual o governo estabelece as principais diretrizes e metas da Administração Pública para o prazo de um exercício) e LOA - Lei Orçamentária Anual (lei que estima os valores da receita e fixa os valores da despesa para determinado exercício).

3. A Lei de Responsabilidade Fiscal, que: define limites para o gasto com pessoal e endividamento público; obriga a publicização de informações financeiras; exige a realização de audiências públicas e o incentivo à participação popular na discussão das leis orçamentárias.

Em síntese: A LDO estabelece as principais diretrizes do orçamento para o próximo ano e precisa estar de acordo com o Plano Plurianual (diretrizes e metas para um período de quatro anos) e a Lei Orçamentária (que fixa os gastos em cada programa), que também são discutidos cada ano. 
Em Curitiba, o orçamento é feito pelas Secretarias e Órgãos com direção da Secretaria Municipal de Finanças e Secretaria de Planejamento, que reúnem as informações na proposta orçamentária, orientada por um conjunto de leis e instruções ${ }^{9}$. Segundo o documento http://www.orcamentos.curitiba.pr.gov.br/LDO_2012_ap.pdf, temos na composição do orçamento municipal:

\section{TIPOS DE RECEITA}

\section{RECEITA PÚBLICA}

É o conjunto de recursos que entram nos cofres do governo. RECEITA CORRENTE É todo recurso que o Município recebe regularmente para gastar com suas atividades básicas. Geralmente vem da arrecadação de impostos pagos pelos cidadãos.

RECEITA CORRENTE LÍQUIDA

É o somatório dos componentes da receita corrente deduzidos alguns itens previstos em dispositivos legais, como, por exemplo, contribuições previdenciárias e receitas intraorçamentárias.

RECEITA DE CAPITAL

São recursos adquiridos por meio da venda de bens e direitos, de doações e convênios com outras entidades e de empréstimos recebidos.

RECEITA PARA CÁLCULO DOS RECURSO DA SAÚDE / EDUCAÇÃO

Base calculada a partir de receitas vindas dos impostos próprios e transferidos da União e do Estado.

\section{TIPOS DE DESPESA}

\section{DESPESA PÚBLICA}

É todo gasto feito pelo governo. Tudo aquilo que o governo se propôs a fazer por meio de um programa, quando for realizado, será anotado como uma despesa pública. Para ser realizado, esse gasto deve ter sido previsto no orçamento que é autorizado pela Câmara Municipal.

DESPESA CORRENTE

São gastos que se destinam à manutenção e ao funcionamento dos serviços públicos realizados pelo Governo.

DESPESA DE CAPITAL

É um gasto realizado para a compra, construção, reforma e ampliação de um bem que aumentará o patrimônio da instituição.

\section{OUTROS TIPOS DE RECEITA E DESPESA}

\section{OPERAÇÃO DE CRÉDITO}

Obtenção de recursos pela administração pública, por meio de empréstimos, com o objetivo de financiar seus projetos.

ALIENAÇÃO DE BENS

Receita proveniente da venda de bens móveis ou imóveis.

INVERSÃO FINANCEIRA

Gastos com aquisição de imóveis em utilização, aquisição de bens para revenda, participação acionária em empresas de economia mista, entre outros.

AMORTIZAÇÃO DA DÍVIDA

\footnotetext{
${ }^{9}$ Constituição Federal - 1988. Lei Orgânica do Município - 1990. Lei Complementar Federal 101/2000 - Lei de Responsabilidade Fiscal. Lei Federal 10.257/2001 - Estatuto da Cidade. Portaria Ministerial MPOG 42/1999, SNT 249/2010 e STN/SOF 04/2010. Instrução Técnica TCE 20/2003 e Alterações. Instrução Normativa TCE 36/2009. Lei Municipal 13.378/2009.
} 
É a diminuição do valor total de uma dívida que ocorre quando o devedor realiza o pagamento de parcelas do seu débito.

RESERVA DE CONTINGÊNCIA

Significa guardar parte do orçamento para eventuais riscos ${ }^{10}$.

RISCO

Evento ou condição incertos que, se ocorrerem, terão efeito positivo ou negativo.

Pinto (2008) argumenta que os orçamentos passaram a se constituir como peças de intervenção do domínio econômico, instrumento de política fiscal, ao mesmo tempo em que as pressões da sociedade civil por direitos sociais amplia o leque de reivindicações e coloca em xeque o formato atual de representação política.

O processo do Ciclo Orçamentário se dá conforme as regras estabelecidas pela Constituição de 1988 e na Lei de Responsabilidade Fiscal de 2000. No município, as regras constitucionais estão inseridas na Lei Orgânica do Município, que prevê:

1. Audiências prévias de consulta pública organizado pelo Poder Executivo, e realizadas nas Administrações Regionais do município ${ }^{11}$;

2. Utilização da página da Prefeitura Municipal de Curitiba na Internet, e-mail da prefeitura e telefone 156 para sugestões e propostas ao orçamento;

3. Audiências públicas de exposição do orçamento já elaborado pelas Secretarias Municipais e demais órgãos da Administração, nas mesmas circunstâncias.

As consultas prévias são organizadas de forma a ouvir a população sobre problemas e reivindicações, que são recebidas pelos representantes do Executivo para possível inclusão no Orçamento, enquanto que nas Audiências Públicas são apresentados os números que fazem parte do orçamento já definido.

No levantamento que realizamos sobre as consultas e audiências públicas entre os anos de 2008 e 2013, verificamos a quase total ausência dos vereadores, cuja presença é detectada apenas entre aqueles que possuem votação expressiva em determinada região onde se realizam as reuniões, mas mesmo assim não ocorre em todos os casos. Verificamos a lista de presença das consultas e audiências da LOA no período estudado. Entre os anos de 2008 e 2011, nas audiências pública ainda é possível apontar a presença de entidades de bairro, de classe e pessoas jurídicas pela identificação, porém a partir de 2012, a exigência de identificação é apenas do nome e telefone de contato, tornando assim impossível saber se há representação ou apenas a presença de pessoas físicas, representantes de secretarias ou assessorias. No caso das consultas, é ainda mais problemático a verificação, pois apenas há a inclusão do nome e assinatura, sem nenhuma identificação funcional ou de representação.

\footnotetext{
${ }^{10}$ Corresponde a $1^{\circ}$ da receita corrente líquida. É desta rubrica que são alocadas as emendas parlamentares do orçamento. ${ }^{11}$ Matriz, Boqueirão, Freguesia, Pinheirinho, CIC, Bairro Novo, Cajuru, Portão, Santa Felicidade.
} 
A consulta divide-se em duas etapas, no mesmo dia, a primeira para debates sobre o tema, e a segunda para organização das propostas ao Executivo.

Das consultas públicas realizadas nas Administrações Regionais da cidade de Curitiba sobre LDO e LOA, selecionamos três para amostra: Bairro Novo, Cajuru, Matriz. A mostra tanto da LDO quanto da LOA tem o significado de apresentar parte do ciclo orçamentário, que se inicia com o Plano Plurianual, de vigência de quatro anos, e que anuncia as diretrizes, objetivos e metas da administração pública para médio prazo, mas que tem na LDO as metas e prioridades que serão orientarão a Lei Orçamentária Anual e as alterações feitas a cada ano no Plano Plurianual.

Regional do Bairro Novo

\begin{tabular}{|c|c|c|c|c|}
\hline Reunião & Data & $\begin{array}{l}\text { Número de } \\
\text { Participantes }\end{array}$ & $\begin{array}{l}\text { Vereadores } \\
\text { presentes }\end{array}$ & $\begin{array}{c}\text { Assessores } \\
\text { presentes }\end{array}$ \\
\hline LDO 2008 & $25 / 04 / 2007$ & 202 & 1 & \\
\hline LOA 2008 & $\begin{array}{c}\text { 08/08/2007 } \\
\text { Debate } \\
\text { Propostas }\end{array}$ & $\begin{array}{l}109 \\
118\end{array}$ & $\begin{array}{l}0 \\
1\end{array}$ & $\begin{array}{l}2 \\
1\end{array}$ \\
\hline LDO 2009 & $\begin{array}{c}\text { 17/04/2008 } \\
\text { Debate } \\
\text { Propostas }\end{array}$ & $\begin{array}{c}123 \\
86\end{array}$ & $\begin{array}{l}0 \\
0\end{array}$ & $\begin{array}{l}0 \\
0\end{array}$ \\
\hline LOA 2009 & $\begin{array}{c}\text { 10/07/2008 } \\
\text { Debate } \\
\text { Propostas }\end{array}$ & $\begin{array}{l}100 \\
100\end{array}$ & $\begin{array}{l}0 \\
0\end{array}$ & $\begin{array}{l}0 \\
0\end{array}$ \\
\hline LDO 2010 & 07/04/2009* & 169 & 0 & 0 \\
\hline $\begin{array}{l}\text { PPA 2010-2013 } \\
\text { LOA } 2010\end{array}$ & $20 / 07 / 2009$ & 123 & 0 & 0 \\
\hline LOA 2011 & 29/07/2010 & 84 & 0 & 0 \\
\hline LDO 2012 & $13 / 04 / 2012$ & 134 & 1 & 0 \\
\hline LOA 2012 & $21 / 07 / 2011$ & 109 & 0 & 0 \\
\hline LDO 2013 & $12 / 04 / 2012$ & 148 & 0 & 0 \\
\hline LOA 2013 & $19 / 07 / 2012$ & 89 & 0 & 0 \\
\hline LDO 2014 & $10 / 04 / 2013$ & $287 * *$ & 2 & 0 \\
\hline
\end{tabular}

* A partir desta data, não há mais distinção na lista de presença entre debate e proposta.

** A partir desta data, o Prefeito comparece nas reuniões. 


\begin{tabular}{|c|c|c|c|c|}
\hline Reunião & Data & $\begin{array}{c}\mathrm{N}^{\mathrm{o}} \mathrm{de} \\
\text { participantes }\end{array}$ & $\begin{array}{l}\text { Vereadores } \\
\text { presentes }\end{array}$ & $\begin{array}{c}\text { Assessores } \\
\text { presentes }\end{array}$ \\
\hline LDO 2008 & $\begin{array}{c}\text { 25/04/2007 } \\
\text { Debate } \\
\text { Proposta }\end{array}$ & $\begin{array}{c}145 \\
96\end{array}$ & $\begin{array}{l}3 \\
1\end{array}$ & $\begin{array}{l}0 \\
0\end{array}$ \\
\hline LOA 2008 & $\begin{array}{c}\text { 08/07/2007 } \\
\text { Debate } \\
\text { Propostas }\end{array}$ & $\begin{array}{l}109 \\
133\end{array}$ & $\begin{array}{l}0 \\
0\end{array}$ & $\begin{array}{l}1 \\
0\end{array}$ \\
\hline LDO 2009 & $\begin{array}{c}\text { 17/04/2008 } \\
\text { Debate } \\
\text { Propostas }\end{array}$ & $\begin{array}{l}102 \\
151\end{array}$ & $\begin{array}{l}1 \\
1\end{array}$ & $\begin{array}{l}0 \\
0\end{array}$ \\
\hline LOA 2009 & $\begin{array}{c}\text { 10/07/2008 } \\
\text { Debate } \\
\text { Propostas }\end{array}$ & $\begin{array}{l}79 \\
95\end{array}$ & $\begin{array}{l}0 \\
0\end{array}$ & \\
\hline LOA 2010 & 08/04/2009* & 176 & 4 & 0 \\
\hline $\begin{array}{c}\text { PPA 2010-2013 } \\
\text { LOA } 2010\end{array}$ & $29 / 07 / 2009$ & 148 & 2 & 0 \\
\hline LDO 2011 & $15 / 04 / 2010$ & 243 & 3 & 0 \\
\hline LOA 2011 & $28 / 07 / 2010$ & 139 & 1 & 0 \\
\hline LDO 2012 & $14 / 04 / 2011$ & 205 & 5 & 0 \\
\hline LOA 2012 & $20 / 07 / 2011$ & 202 & 1 & 0 \\
\hline LDO 2013 & $11 / 04 / 2012$ & 153 & 5 & 0 \\
\hline LOA 2013 & $18 / 07 / 2012$ & 124 & 0 & 0 \\
\hline LDO 2014 & $17 / 04 / 2013$ & 426 & 4 & 0 \\
\hline
\end{tabular}

* A partir desta data, não há mais distinção na lista de presença entre debate e proposta.

Regional da Matriz

\begin{tabular}{|c|c|c|c|c|}
\hline Reunião & Data & $\begin{array}{c}\mathrm{N}^{\mathrm{o}} \text { de } \\
\text { participantes }\end{array}$ & $\begin{array}{c}\text { Vereadores } \\
\text { presentes }\end{array}$ & $\begin{array}{c}\text { Assessores } \\
\text { presentes }\end{array}$ \\
\hline LDO 2008 & $\begin{array}{c}\text { 26/05/2007 } \\
\text { Debate } \\
\text { Proposta }\end{array}$ & $\begin{array}{l}132 \\
111\end{array}$ & $\begin{array}{l}1 \\
0\end{array}$ & $\begin{array}{l}0 \\
0\end{array}$ \\
\hline LOA 2008 & $\begin{array}{c}\text { 09/08/2007 } \\
\text { Debate } \\
\text { Proposta }\end{array}$ & $\begin{array}{c}102 \\
98\end{array}$ & $\begin{array}{l}1 \\
1\end{array}$ & $\begin{array}{l}0 \\
0\end{array}$ \\
\hline LDO 2009 & $14 / 04 / 2008$ & 62 & 0 & 0 \\
\hline LDO 2009 & $14 / 04 / 2008$ & 77 & 0 & 0 \\
\hline LOA 2009 & $11 / 07 / 2008$ & & & \\
\hline
\end{tabular}




\begin{tabular}{|c|c|c|c|c|} 
& $\begin{array}{c}\text { Debate } \\
\text { Proposta }\end{array}$ & 65 & 0 & 0 \\
\hline LDO 2010 & $06 / 04 / 2009 *$ & 93 & 0 & 0 \\
\hline LDO 2011 & $13 / 04 / 2010$ & 118 & 0 & 0 \\
\hline LOA 2011 & $27 / 10 / 2010$ & 88 & 0 & 0 \\
\hline LDO 2012 & $12 / 04 / 2011$ & 132 & 1 & 0 \\
\hline LOA 2012 & $21 / 07 / 2011$ & 75 & 0 & 0 \\
\hline LDO 2013 & $12 / 04 / 2012$ & 102 & 1 & 0 \\
\hline LOA 2013 & $19 / 07 / 2012$ & 95 & 0 & 0 \\
\hline
\end{tabular}

* A partir desta data, não há mais distinção na lista de presença entre debate e proposta.

O público das audiências públicas organizadas pelo poder executivo é composto de servidores das diversas secretarias, autarquias e assessorias e entidades de classe, corporativas e de moradores, além de moradores das áreas de interesse nas regiões em que se realizam as audiências. Verifica-se porém a aleatoriedade do processo: nas listas de presença das audiências públicas, não há sistematização de controle, ficando a critério dos envolvidos a identificação funcional ou corporativa ou de representação. Em algumas listas, ocorre esta identificação, em outras apenas o nome e a assinatura, o que dificulta a organização dos dados para análise. Em outras, somente é registrada a sigla da entidade. Verificamos, portanto, que há pouca cientificidade e objetividade no processo de consultas e audiências públicas, pelo processo amador e aleatório de registro de presença da população, organizada ou não, e entidades comunitárias, setoriais ou de classe que não possuem atendimento diferenciado, tendo em vista a representatividade que possuem.

Audiências Públicas - Orçamento - 2008/20213

\begin{tabular}{|c|c|c|c|c|c|}
\hline Reunião & Participantes* & Pessoa física & Prefeitura & Entidades & Vereadores \\
\hline LOA 2008 & 111 & 52 & 36 & 11 & 0 \\
\hline LOA 2009 & 140 & 30 & 88 & 16 & 1 \\
\hline LOA 2010 & 152 & 96 & 20 & 11 & 1 \\
\hline $\begin{array}{r}\text { PPA 2010-2013 /LOA } \\
\text { 2011 }\end{array}$ & 115 & 35 & 49 & 6 & 4 \\
\hline LOA 2011 & 114 & 7 & 79 & 20 & 2 \\
\hline LOA 2012 & 144 & 90 & 13 & 8 & 0 \\
\hline LOA 2013 & 148 & 148 & 29 & 1 & 0 \\
\hline LOA 2014 & $164 * *$ & - & - & - & 3 \\
\hline
\end{tabular}


PPA 2014-2017

LOA 2014

* Nem sempre coincide o número de participantes com os números de entidades e da prefeitura, evidenciando a aleatoriedade do processo.

** Apenas o nome e a assinatura, não há outra identificação.

Como verificamos, a presença dos parlamentares é mínima nos debates e consultas e nas audiências públicas sobre questões de orçamento. O registro destas reuniões é precário até o ano de 2012, quando há a sistematização dos dados para consulta na Internet, a partir das exigências de transparência nas contas públicas. Em todas as audiências, há apenas uma com Ata, em que aparece a discussão sobre a inclusão de duas ruas no programa de pavimentação. No restante, há apenas a possibilidade de consulta nas listas de presença, precárias e com falta de informações relevantes.

A partir de 2012, ocorre o processo de informatização do conteúdo das consultas e das audiências públicas, na página da Prefeitura, no Portal da Transparência, onde é possível verificar a sistematização de dados estatísticos relativos às consultas ${ }^{12}$ e audiências públicas ${ }^{13}$. Até então, não há possibilidade de organizar informações para análise além das apresentadas acima, tendo em vista a ausência de Atas de reunião, sugestões publicizadas e sistematização de propostas apresentadas ao poder executivo.

Na página da Prefeitura relativa ao Orçamento, a partir do ano de 2012 as informações sobre as prioridades da população sobre o que deve ser trabalhado pelo setor público estão catalogadas em forma de estatística, a partir da organização e sistematização das sugestões e reivindicações realizadas junto aos canais de participação da prefeitura. As prioridades da população consultada foram: vias, segurança, trânsito, saúde e transporte.

$\begin{array}{cc}\text { LDO + LOA } 2012 & \\ \text { CANAL } & \text { ACESSO } \\ 156 & 1088 \\ \text { Consultas Públicas } & 5785 \\ \text { CRM } * & 7304 \\ \text { Internet } & 11.398 \\ \text { Total } & 22.575\end{array}$

Fonte: http://www.orcamentos.curitiba.pr.gov.br/LOA_2012_ap.pdf

* Central de Relacionamento Municipal - pesquisa realizada pelo Instituto Curitiba de Informática sobre Orçamento dirigida à população, com participação nas Audiências Públicas, de forma presencial.

\footnotetext{
${ }^{12}$ http://www.orcamentos.curitiba.pr.gov.br/LDO_2012_cd tabulacao.pdf http://www.orcamentos.curitiba.pr.gov.br/LOA_2012_cd_tabulacao.pdf

${ }^{13}$ http://www.orcamentos.curitiba.pr.gov.br/LDO_2012_ap.pdf http://www.orcamentos.curitiba.pr.gov.br/LOA 2012 ap.pdf http://www.orcamentos.curitiba.pr.gov.br/LDO_2013.pdf http://www.orcamentos.curitiba.pr.gov.br/LOA_2013_ap.pdf
} 
Conforme disponibiliza a página da Prefeitura na Internet, temos para o Orçamento:

$2012-25.575$ sugestões

\begin{tabular}{|c|c|}
\hline Consultas Proativas & $28,6 \%$ \\
\hline Consultas Públicas & $26,8 \%$ \\
\hline Internet & $44,6 \%$ \\
\hline
\end{tabular}

Fonte: http://www.orcamentos.curitiba.pr.gov.br/LOA_2012_ap.pdf

$2013-22.331$ sugestões

\begin{tabular}{|c|c|}
\hline 156 & $7,53 \%$ \\
\hline Consultas Públicas & $14,19 \%$ \\
\hline CRM & $32,28 \%$ \\
\hline Internet & $46,00 \%$ \\
\hline
\end{tabular}

Fonte: http://www.orcamentos.curitiba.pr.gov.br/LOA_2013_ap.pdf

As prioridades apontadas pela população consultada continuam as mesmas: vias, segurança, trânsito, saúde e transporte.

Trata-se na verdade de publicização de generalidades sobre o Orçamento Público, apresentada por técnicos ou secretários municipais, com o objetivo de cumprir as leis e normas vigentes. Não há efetivamente alteração no Orçamento por intervenção popular ou corporativa nas apresentações, mas a sociedade organizada que tem poder de articulação com o setor público de alguma maneira já fez parte da elaboração do Orçamento. Conselho Regional de Engenharia eAgronomia do Paraná, Asociação Comercial do Paraná, Sindicato dos Logistas do Comércio estabelecidos em Shoppings Centers de Curitiba, Federação das Indústrias do Estado do Paraná, são instituições que participam da elaboração do Orçamento já na sua gênese, interferindo de maneira a moldar a cidade aos seus projetos.

\section{Emendas Parlamentares - a que será que se destina?}

A partir de 2013, após a mudança de legislatura e do grupo político que se estabelece no poder, com grande renovação legislativa, não são encontrados grandes sobressaltos no Orçamento, que apresenta a configuração usual de anos anteriores.

A partir de 2006, o Poder Executivo fixou um determinado valor da Reserva de Contingência para os vereadores utilizarem na formulação de emendas parlamentares. A fixação de valores para a elaboração de emendas, por um lado diminui o conflito constante ao longo de anos anteriores, em que havia "constante circulação de benefícios aos aliados" (Nazareno, 2006) e dificuldade de 
concretização das emendas por parte da oposição; por outro este pacto garante aos vereadores e ao prefeito um "sistema de incentivos como um elemento estruturante de apoio e sustento de um grupo no poder, utilizado pela organização como estratégia de sobrevivência política. (p.231, citando Diniz, 1988)

Isso demonstra a centralidade da atividade legislativa nas emendas parlamentares, no que se refere ao orçamento. O Poder Executivo, ao fixar valores da Reserva de Contingência para serem utilizados pelos vereadores para emendas individuais ou coletivas, para assuntos pontuais ou de alcance mais amplo, acomoda interesses eleitorais e diminui o tensionamento entre os poderes.

\begin{tabular}{|l|c|c|c|c|c|c|}
\hline \multicolumn{1}{|c|}{ ANO } & 2008 & 2009 & 2010 & 2011 & 2012 & 2013 \\
\hline Valor por Vereador & $400.000,00$ & $450.000,00$ & $470.000,00$ & $600.000,00$ & $600.000,00$ & $500.000,00$ \\
Valor Total & $15.220 .000,00$ & $17.100 .000,00$ & $17.860 .000,00$ & $22.800 .000,00$ & $22.800 .000,00$ & $19.000 .000,00$ \\
\hline
\end{tabular}

Fonte: Comisão de Economia, Finanças e Fiscalização da Câmara Municipal de Curitiba.

A cidade de Curitiba tem seu parlamento composto por 38 Vereadores, número definido em lei, proporcional ao número de habitantes da cidade. Temos na Câmara Municipal de Curitiba, no período analisado, na qualidade de Vereadores, representantes de vários setores: Ministro de Igrejas; ex-jogadores de futebol; empresários; radialistas; advogados; sindicalistas; jornalistas; assessores parlamentares; sucessores de políticos; presidentes de associações de classe e de bairro; engenheiro; dentista; gestores públicos; funcionários públicos.

Nazareno (2009) nos apresenta uma categorização que a nosso ver abrange quase a totalidade dos vereadores da capital. Para ela, é possível dividir os vereadores em quatro categorias gerais:

1. Comunitários: vereadores com origem em associações de bairro, grupos de bairro da escola ou defensores de interesses de bairro, com escritórios regionais nas comunidades para atendimento à população;

2. Midiáticos: principal atividade na mídia, com exposição de imagem pública anterior às eleições nos diversos meios de comunicação (TV, jornais, rádio). Aparecem principalmente a partir de atividades esportivas e policiais.

3. Temático institucionais: vereadores participam de atividades específicas como sindicatos, movimentos ecológicos e religiosos. Possuem experiência política anterior de organização e participação em categorias de reivindicação política, entre os mais organizados com unidade suficiente para lançar candidato único. 
4. Funcionários políticos: carreira política alavancada por ligações com outros políticos e caminhos percorridos por vínculos familiares.

Essa classificação, como veremos, serve de base para os parlamentares de Curitiba, sem, no entanto, estabelecer um limite rígido, na medida em que misturam-se as categorizações para vários vereadores, pela multiplicidade de formação, atividades anteriores e modos de atuação.

As eleições de 2012 em Curitiba nos apresentaram um quadro de votação como definido abaixo, que traz como característica principal a divisão por áreas - centralizada ou difusa - que se definem a partir das categorias conceituadas por Nazareno, porém com nuances e particularidades próprias de cada município.

Os vereadores comunitários concentram suas votações em localidades definidas de atuação.

Aldemir Manfron - concentra sua atividade em Santa Felicidade, onde tem comércio e escritório político. Ex-presidente da Sociedade Operária Beneficente Esportiva Iguaçu, do mesmo bairro.

Aladim Luciano - empresário comerciante na região do Bacacheri com forte concentração de voto nesse bairro. Ex-jogador de futebol.

Beto Moraes - sucessor do Deputado Mauro Moraes, de quem foi assessor, desenvolve trabalho assistencial nos bairros mais pobres. Adotou o sobrenome Moraes para manter o poder político nos redutos eleitorais.

Cacá Pereira - ex-presidente da Associação de Moradores e Amigos do Itatiaia (Amai) e vicepresidente da União das Entidades Comunitárias da CIC. Também é secretário-geral do Novo Mundo Futebol Clube.

Chico do Uberaba - ex-residente da Associação Comercial e Industrial do Uberaba, Guabirotuba e Jardim das Américas.

Dirceu Moreira - ex-presidente da Associação de Moradores da Vila Nossa Aparecida (Cidade Industrial).

Dona Lourdes - possui centro de atendimento de assistência social no bairro de Santa Quitéria.

Geovane Fernandes - ex-gestor público na Regional do Boqueirão; Conselheiro de saúde da Unidade Municipal de Saúde Tapajós e Presidente do Conselho Comunitário de Segurança (Conseg) do Xaxim.

Jairo Marcelino - ex-comerciante e ex-motorista profissional. Vereador desde 1982, é o $8^{\circ}$ mandato, com sua maior votação no bairro da Barreirinha e adjacências.

Mestre Pop - ex-presidente da Associação Moradias Rio Bonito, no bairro Campo de Santana. Líder de projetos sociais para as escolas públicas.

Paulo Rink (PPS) - Ex-jogador de futebol, empresário desde 2000, é um dos participantes do programa assistencial Gols pela Vida, uma parceria do Instituto de Pesquisa Pelé com o Hospital Pequeno Príncipe.

Pedro Paulo - professor da rede municipal de educação e iniciou a militância política a partir de sua inserção em comunidades eclesiais de base, onde participou das pastorais da Juventude e Operária. 
Rogério Campos - motorista de ônibus desde 2002, é da diretoria do Sindicato dos Motoristas e Cobradores de Curitiba e Região Metropolitana (Sindimoc). Antes disso, durante cinco anos, havia trabalhado como cobrador.

Serginho do Posto - participou da fundação da Associação Comercial do Cajuru (AECAJ) e foi vicepresidente da entidade.

Tico Kuzma - comerciante, representante do Capão Raso e adjacências.

Tito Zeglin - representante da Igreja Católica, e dos bairros Capão Raso, Tatuquara e Pinheirinho.

Toninho da Farmácia - como proprietário de farmácia há 30 anos no bairro da Cidade Industrial de Curitiba, concentra neste bairro sua votação.

Os vereadores midiáticos obtém votação espalhada, distribuída em toda a cidade, sem um bairro ou região de concentração de votos. São radialistas principalmente nas atividades ligadas a programas policiais ou esportivos ou utilizam de estratégia midiática em suas várias formas de exposição.

Cristiano Santos - apresenta o Jornal da Tarde, na Rádio Difusora AM 590, e divide a apresentação do Programa 190, na Rede CNT, com o pai, o deputado estadual Roberto Aciolli (PV);

Colpani - Radialista, apresentador de programa de TV de variedades e colunista de jornal.

Professor Galdino - Professor, utiliza mídia pessoal de exposição em espaços públicos, com música, bicicleta tipo triciclo e aparatos luminosos.

Os vereadores temáticos institucionais possuem experiência política no sentido amplo, como representantes de Igrejas, representantes de entidades de classe, ensino, atividades profissionais, cooperativas e associações, entre outros. Também apresentam resultados eleitorais em todo o município, sem concentração de votação.

Ailton Araújo - Ministro da Igreja do Evangelho Quadrangular.

Carla Cristina - Missionária da Igreja Evangélica Assembléia de Deus no Paraná.

Chicarelli - Ex-presidente da Associação de Restaurantes, Hotéis e Pousadas do Litoral Paranaense. Foi vice-presidente da Associação Siloé de Apoio Social (Asas), vinculada à $4^{\circ}$ Igreja do Evangelho Quadrangular.

Jorge Bernardi - Vice-reitor do Centro Universitário Uninter. doutorando, mestre e especialista em Gestão Urbana pela Pontifícia Universidade Católica do Paraná (PUC-PR). Especialista em Formação de Docentes e Orientadores Acadêmicos em Ensino a Distância (EAD).

Noêmia Rocha - evangélica, membro da Igreja Evangélica Assembleia de Deus.

Paulo Salamuni - Ex-integrante do Conselho Municipal de Combate às Drogas e Entorpecentes (1986/1988); presidiu a Associação dos Meninos de Rua e Curitiba (1991/1992); e foi membro das comissões de Direitos Humanos (1991/1993) e de Cidadania (1998/2000) da Ordem dos Advogados do Brasil no Paraná. 
Professora Josete - Integrou a equipe que criou o Sindicato dos Servidores do Magistério Municipal de Curitiba (Sismmac). Foi presidente do Sismmac e dirigente estadual da Central Única dos Trabalhadores (CUT).

Pastor Valdemir - Conferencista evangélico da Igreja Universal, ex-presidente da Companhia Popular de Habitação de Curitiba (Cohab-CT).

Zé Maria - empresário no ramo de imóveis; membro do Rotary Club de Curitiba Leste; Maçom. Expresidente da Escola de Educação Especial Primavera.

Os vereadores funcionários políticos iniciaram a vida política na qualidade de assessores parlamentares, diretores de estatais ou órgãos da administração pública e alguns como funcionários públicos de carreira. Outros se destacam pelo parentesco com políticos, em formação de estrutura de parentesco no legislativo. Como destaca Oliveira (2012): "Família ainda importa." (p. 13) Da mesma maneira, possuem votação pulverizada em todo o município.

Bruno Pessuti - Filho do Ex-deputado e Vice-Governador Orlando Pessuti. Engenheiro do Instituto de Tecnologia para o Desenvolvimento (Lactec) e Instituto de Tecnologia do Paraná (Tecpar), empresas do Estado.

Felipe Braga Cortes - Filho do ex-deputado Fabiano Braga Côrtes e sobrinho do ex-governador Ney Braga. Ex-diretor da Cohab (Companhia de Habitação Popular) de Curitiba.

Hélio Wirbiski - Entre 2011 e 2012, foi secretário Municipal de Relações Institucionais. Além disso, diretor-geral da Secretaria Municipal de Administração, superintendente administrativo da Itaipu Binacional e assessor parlamentar na Assembleia Legislativa do Paraná.

Jonny Stica - Filho do ex-vereador e ex-deputado estadual Natálio Stica. Presidiu o centro acadêmico da graduação de Arquitetura da PUC/PR e o Diretório Central de Estudantes.

Julieta Reis - Prima do ex-governador Ney Braga, desde 1973 é servidora da prefeitura de Curitiba. Fez parte da equipe que organizou a Fundação Cultural, a Feira de Artesanato do Largo da Ordem, o Bondinho da Rua XV, o Centro de Criatividade do Parque São Lourenço e a Casa do Artesanato.

Mauro Ignácio (PSB) - Funcionário publico estadual desde 1982 (SEED), formado em Administração de Empresas, pós-graduado em Tecnologia da Informação e Administração Pública. Ex-diretor das Relações do Trabalho na Secretaria Municipal do Trabalho e Emprego.

Pierpaolo Petruzziello - Ex-assessor parlamentar do deputado estadual Alexandre Curi (PMDB), foi superintendente de Regularização Fundiária da Companhia de Habitação do Paraná (Cohapar).

Sabino Picolo - ex-funcionário do Banestado. Eleito pela categoria dos bancários inicialmente.

Tiago Gevert - ex-assessor parlamentar do deputado federal Ratinho Jr. (PSC). É presidente do PSC Jovem no Paraná, tesoureiro nacional da Juventude do PSC, $1^{\circ}$ tesoureiro do PSC paranaense.

A amostra será de vereadores das legislaturas 2010 e 2013, tendo como foco os vereadores que se reelegeram. A proporção encontrada nestas duas legislaturas é praticamente a mesma: 


\begin{tabular}{|c|c|}
\hline $\mathbf{2 0 0 8}$ & 2012 \\
5 midiáticos & 3 midiáticos \\
\hline 10 temáticos & 9 temáticos \\
\hline 16 comunitários & 17 comunitários \\
\hline 7 funcionários políticos & 9 funcionários políticos \\
\hline
\end{tabular}

Para cada grupo escolhido, selecionamos um número respectivo de emendas apresentadas, chamadas Emendas Aditivas, que são as emendas que aditam valores à lei orçamentária por meio de despesa de capital (investimento) ou custeio (manutenção). Este tipo de emenda acrescenta ao orçamento valores não previstos, indicadas pelos gabinetes parlamentares e com recursos da Reserva de Contingência.

As emendas são elaboradas a partir de indicações dos gabinetes de vereadores ao corpo técnico da Comissão de Economia, que organiza-as a partir de critérios técnicos. As emendas são protocoladas e enviadas ao Plenário para votação em duas sessões. O Projeto de Lei Orçamentária é enviado à Prefeitura com as emendas para correção e finalização da Lei Orçamentária.

Para fins didáticos, apresentaremos um modelo de emenda de investimento e emenda de custeio, como forma de exemplificar o resultado.

\section{Emenda de investimento}

Adite-se ao Órgão Orçamentário 33000 - Fundo Municipal de Saúde, na Unidade Orçamentária 33001 - Gabinete do Presidente, no Projeto com classificação orçamentária 33001.10302.0055.1035 - AQUISIÇÃO E REPOSIÇÃO DE EQUIPAMENTOS E MATERIAL PERMANENTE, no elemento de despesa, com a respectiva fonte e valor, conforme abaixo especificado.

\begin{tabular}{|c|c|c|c|}
\hline $\begin{array}{c}\text { Elemento de } \\
\text { Despesa }\end{array}$ & Discriminação & Fonte & Valores em Reais \\
\hline 4.4 .90 .52 .00 .00 & $\begin{array}{l}\text { Equipamentos e Material } \\
\text { Permanente }\end{array}$ & $0-1-303$ & $\mathrm{R} \$ 260.000,00$ \\
\hline \multicolumn{2}{|c|}{ Total da Adição de Valores no Projeto 1035 } & $\mathrm{R} \$ 260.000,00$ \\
\hline
\end{tabular}

Para suporte da adição supra, reduza-se do Órgão Orçamentário 24000 - Reserva de Contingência, na Unidade Orçamentária 24001 - Reserva de Contingência, na Operação Especial com classificação orçamentária 24001.99999.9999.9001 - Reserva de recursos para atender passivos contingentes, outros riscos fiscais imprevistos e 
demais legislações vigentes, conforme Lei Complementar Federal, n. 101, de 04 de maio de 2000 do elemento de despesa, com a respectiva fonte e valor, conforme abaixo especificado:

\begin{tabular}{|c|c|c|c|}
\hline $\begin{array}{c}\text { Elemento de } \\
\text { Despesa }\end{array}$ & Discriminação & Fonte & Valores em Reais \\
\hline 9.9 .99 .99 .99 .00 & Reserva de Contingência & $9-9-999$ & $\mathrm{R} \$ 260.000,00$ \\
\hline \multicolumn{2}{|l}{ Total da Anulação de Valores da Operação Especial 9001} & $\mathrm{R} \$ 260.000,00$ \\
\hline
\end{tabular}

Modifique-se para a redação final, em razão da emenda proposta, os demais quadros e anexos componentes do Projeto da Lei Orçamentária para o exercício de 2011.

\section{Emenda de custeio}

Adite-se ao Órgão Orçamentário 28000 - Fundação Cultural de Curitiba, na Unidade Orçamentária 28001 - Gabinete do Presidente, na Atividade com classificação orçamentária 28001.13392.0048.2002 DESENVOLVIMENTO DE PROGRAMAS DE PROMOÇÃO E DIFUSÃO DE ATIVIDADES ARTÍSTICAS E CULTURAIS, PROTEÇÃO AO PATRIMÔNIO HISTÓRICO, ARTÍSTICO E CULTURAL, no elemento de despesa, com a respectiva fonte e valor, conforme abaixo especificado:

\begin{tabular}{|c|c|c|c}
\hline $\begin{array}{c}\text { Elemento de } \\
\text { Despesa }\end{array}$ & Discriminação & Fonte & Valores em Reais \\
\hline 3.3 .90 .39 .00 .00 & $\begin{array}{c}\text { Outros Serviços de } \\
\text { Terceiros- Pessoa Jurídica }\end{array}$ & $0-1-001$ & $\mathrm{R} \$ 260.000,00$ \\
\hline \multicolumn{2}{|l|}{ Total da Adição de Valores na Atividade 2002 } & $\mathrm{R} \$ 260.000,00$ \\
\hline
\end{tabular}

Para suporte da adição supra, reduza-se do Órgão Orçamentário 24000 - Reserva de Contingência, na Unidade Orçamentária 24001 - Reserva de Contingência, na Operação Especial com classificação orçamentária 24001.99999.9999.9001 - Reserva de recursos para atender passivos contingentes, outros riscos fiscais imprevistos e demais legislações vigentes, conforme Lei Complementar Federal, n. 101, de 04 de maio de 2000 do elemento de despesa, com a respectiva fonte e valor, conforme abaixo especificado:

\begin{tabular}{|c|c|c|c|}
\hline $\begin{array}{c}\text { Elemento de } \\
\text { Despesa }\end{array}$ & Discriminação & Fonte & Valores em Reais \\
\hline 9.9 .99 .99 .99 .00 & Reserva de Contingência & $9-9-999$ & $\mathrm{R} \$ 260.000,00$ \\
\hline \multicolumn{2}{|l|}{ Total da Anulação de Valores da Operação Especial 9001} & $\mathrm{R} \$ 260.000,00$ \\
\hline
\end{tabular}

Modifique-se para a redação final, em razão da emenda proposta, os demais quadros e anexos componentes do Projeto da Lei Orçamentária para o exercício de 2011. 
A emenda orçamentária não tem as mesmas características, ainda que seja objeto de troca político-representativa, nem a mesma destinação dos requerimentos, que são enviados ao executivo por protocolo simplesmente. Requer técnica legislativa e enquadramento nas normas do orçamento municipal. É submetido à discussão na comissão de Economia, Finanças e Fiscalização e também ao plenário, que é o centro de debate político, e onde são tomadas decisões que levam em consideração os posicionamentos partidários, de situação e de oposição. Afinal, trata-se de alteração no orçamento, ainda que residual, mas que tem que ser enquadrado no projeto do executivo, que sofre modificação, aprovação, sanção do prefeito, isto é, obedece a rituais e caminhos de maior duração e complexidade.

A partir de 2006, o Poder Executivo fixou um determinado valor da Reserva de Contingência para os vereadores utilizarem na formulação de emendas parlamentares. A fixação de valores para a elaboração de emendas, por um lado diminui o conflito constante ao longo de anos anteriores, em que havia "constante circulação de benefícios aos aliados" (Nazareno, 2006) e difículdade de concretização das emendas por parte da oposição; por outro este pacto garante aos vereadores e ao prefeito um "sistema de incentivos como um elemento estruturante de apoio e sustento de um grupo no poder, utilizado pela organização como estratégia de sobrevivência política." (p.231, citando Diniz, 1988)

Isso demonstra a centralidade da atividade legislativa nas emendas parlamentares, no que se refere ao atendimento e a manutenção da conexão eleitoral, desta vez em torno do orçamento.

O orçamento municipal é de inteira responsabilidade do poder executivo no momento de sua elaboração e execução, em que pesem as consultas à população em audiências públicas, o que poderia significar alguma pressão da sociedade organizada por direitos sociais. À diferença do orçamento participativo, em que membros da comunidade organizada deliberam conjuntamente com a administração pública sobre prioridades e participam da elaboração do documento final, com influência efetiva sobre as políticas públicas, no orçamento que colocamos em questão há, por força de lei, a consulta pública onde são ouvidas sugestões, acatadas ou não pelo executivo. Segue-se a exposição da peça orçamentária, calhamaço técnico recheado de números que é apresentado à população, o que caracteriza muito mais informação do que participação. Mesmo na fase de consulta, onde há debate da administração com o público, as questões são pontuais e não dizem respeito a macroeconomia ou ao planejamento de médio e longo prazo. A destinação das sugestões é incerta, fica sob responsabilidade dos gabinetes dos secretários municipais. Se forem acatadas diluem-se dentro de rubricas administrativas e tornam-se parte do conjunto do orçamento. 
Se por um lado o Poder Executivo tem a iniciativa privativa sobre as questões financeiras e orçamentárias do município, ao Legislativo cabe a discussão e aprovação do orçamento, portanto formalmente, dentro do ciclo orçamentário amplo, os dois poderes concorrem para a elaboração, apreciação e aprovação, execução e fiscalização das leis que regem as atividades do poder público. No entanto, há o predomínio efetivo do Poder Executivo na elaboração e execução orçamentária, cabendo ao Poder Legislativo a alocação de emendas parlamentares como apêndice, de valor insignificante do ponto de vista da totalidade orçamentária do município, mas que exerce papel importante na relação dos parlamentes com a comunidade e altera o conteúdo do orçamento, mas em seu aspecto macroeconômico somente, isto é, as emendas são incorporadas às rubricas das secretarias e autarquias para composição da lei orçamentária. A identidade da emenda é diluída nos valores globais, não há mais a assinatura do vereador sobre ela.

No período de tempo em que o Orçamento permanece na Câmara Municipal, de mais ou menos 75 dias, ocorrem debates, consultas e audiência pública que em tese sugerem ampliação do leque de participação e propostas que, segundo Pinto (2006) possibilitariam "realocação de receitas, redesenho de despesas e alterações no curso da execução orçamentária" (p.94) No entanto, o que se acrescenta ao Orçamento são as Emendas Parlamentares, que não compromete o conjunto da peça orçamentária e do programa de governo e passam a fazer parte das atividades corriqueiras dos vereadores. A organização das emendas possibilita, por um lado, mais um tipo de conexão com o representado mas, por outro, perde-se o caráter fiscalizador das finanças do município. A ausência dos vereadores em toda construção do orçamento sinaliza essa preferência pela inserção das emendas no mesmo conjunto que os requerimentos.

O poder executivo, ao fixar valores para serem utilizados pelos vereadores para emendas individuais ou coletivas, para assuntos pontuais ou de alcance mais amplo, acomoda interesses eleitorais e diminui o tensionamento entre os poderes. O poder legislativo, por seu turno, abre mão da possibilidade de intervenção na política macroeconômica do município e do papel de fiscalizador do poder executivo.

\subsubsection{A intermediação legislativa e sua eficácia - conexões representativas}

A produção legislativa da Câmara Municipal de Curitiba se organiza em várias "frentes de trabalho", as quais demonstram a diversidade da representação parlamentar frente ao município e à sua população. Apresentamos as quatro atividades que consideramos significativas para nossa análise, e que praticamente ocupam quase todo o tempo todo do trabalho parlamentar: os projetos de lei ordinária nos quais se enquadram os prêmios e homenagens, e que caracterizem o trabalho 
desenvolvido pelos vereadores dentro do plenário e das comissões da Câmara Municipal, com interlocução especializada com os outros vereadores; os requerimentos de solicitações da população que são encaminhados à prefeitura e outros órgãos do poder público, os quais se constituem como outro tipo de ligação com os representados e entre os poderes; da mesma forma os dois seguintes tipos de atividades indicam esta conexão: as indicações, que são sugestões legislativas ao poder executivo para que este apresente projetos sobre assuntos que não são da alçada do poder legislativo; e as emendas parlamentares ao orçamento, que são apresentadas após seleção de pedidos da sociedade civil que são encaminhadas aos vereadores, a partir de verba definida pelo poder executivo, e que têm o significado de participação no orçamento municipal.

Em todas essas atividades, qualitativamente diferentes, ocorre de determinada forma a construção de uma rede político-eleitoral entre o vereador, a população e o poder executivo, com predomínio da intermediação de interesses construídas a partir das solicitações do eleitorado e encaminhamento ao executivo. O trabalho que determina a construção de uma rede simbólica de troca também não deve ser desconsiderado. O predomínio do uso de alguns desses recursos frente a outros que caracteriza o "fazer" cotidiano dos vereadores, é o que nos aproxima mais da realidade e possibilita vislumbrar as atividades legislativas concreta além das definições abstratas - legislar, julgar, fiscalizar e administrar. Ou, na visão de d"Ávila (2011), os diversos usos que os vereadores oferecem para o exercício de representação, a partir de diferentes estratégias e táticas, tanto dentro quanto fora do parlamento. "Para além de nossas definições canônicas, a observação destes padrões de troca política sugere outras concepções de representação adotadas pelos atores políticos envolvidos." (p.187).

Os trabalhos acadêmicos que focalizaram o tema dão conta de vários aspectos da atividade parlamentar, com ênfase em algumas características peculiares de diferentes legislativos. Apesar da consideração de que há diferenças pouco desprezíveis entre as milhares de Câmaras Municipais no país, no que diz respeito às preferências da atividade parlamentar, a composição dos vereadores, a relação legislativo-executivo, etc., podemos verificar que já há uma gama considerável de discussão sobre o poder legislativo municipal, em forma de estudos de caso, tendo como base as análises dos níveis federal e estadual do poder legislativo. Temos então trabalhos em quantidade suficiente para um balanço importante.

Em nosso trabalho, partimos da premissa de que as instituições políticas apresentam uma lógica própria de funcionamento e relacionamento entre si, com regras internas definidas, que determinam a atuação dos vereadores e a troca com o público demandante. Por mais que aparentemente haja informalidade nas relações estabelecidas entre o vereador, o eleitorado e o poder executivo, a ação legislativa somente se realiza dentro do protocolo, do documento, da requisição, do 
requerimento, do projeto de lei, etc.. Consideramos de que as instituições estruturam e ordenam o comportamento político dos atores em suas atividades cotidianas. Mesmo que essas práticas não sejam eficazes, são adotadas como práticas institucionais que conduzem o jogo político.

Não podemos afirmar, no entanto, que a atividade principal dos vereadores seja a ação em busca do atendimento individual, como nos dá a impressão pela quantidade de requerimentos apresentada, em proporção à pouca aprovação de projetos de lei. Claro que é bem importante a resolução das demandas, mas o cotidiano do vereador é preenchido por inúmeras outras possibilidades, que exigem a postura político partidária e implica em estratégias de comportamento frente a assuntos de maior envergadura, como ocorre no plenário ou nas comissões. São orientados em sua atuação pela linha partidária ou, pelo menos, relacionada à situação dentro da composição de maioria ou minoria. De qualquer maneira, exige preparação política, seja retórica, seja de articulação. As decisões nesta área não são do tipo distributivas, e compõem também a atividade parlamentar.

No levantamento que realizamos, podemos perceber que a dinâmica da atividade legislativa tem diferentes formas, dentro do quadro dos vereadores que compõem a Câmara de Curitiba. Alguns priorizam o atendimento individual, na forma de requerimentos. Outros se apresentam como portavozes de setores organizados, e têm na produção de projetos de lei sua prioridade. A concessão de prêmios e homenagens também ocupam lugar importante na relação política que se estabelece no nível simbólico. A ocupação da tribuna e a publicização de posições controvertidas também configuram atuações parlamentares.

$\mathrm{Na}$ medida em que as questões mais importantes que dizem respeito à configuração das políticas públicas estão sob controle do poder executivo, ao legislativo cabe medidas que lhe possibilite interlocução com a população, na ação legislativa no sentido amplo, ou seja, ações que possuem o objetivo de formação da rede político-representativa, com a intenção de mediação entre a população e o poder executivo. Cada vereador possui uma estratégia, que adota em sintonia com seu perfil e o perfil do público com que se relaciona. Estas ações são legítimas, são sempre trocas políticas, assimétricas, e segundo d'Ávila $\mathrm{F}^{\mathrm{o}}$, se referem aos recursos patrimoniais do Estado sob gestão dos poderes públicos. Acrescentaríamos que as trocas simbólicas exercidas pela concessão de prêmios e homenagens também apresentam esse caráter, ou seja, o de obtenção de benesses não de valor patrimonial, mas sim cerimonial e de reconhecimento simbólico.

A literatura sobre a representação política municipal possui a característica de evidenciar aspectos particulares da ação legislativa, com predomínio em estudos de caso.

O levantamento organizado por Silva (2013) evidencia este aspecto: estudos sobre os modelos de negociação entre o executivo e o legislativo; a prática clientelista; os contextos políticos diferenciados ao longo da história; partidos políticos; elites políticas municipais; distribuição 
geográfica de votos e outros com a mesma importância de conteúdo e de metodologia. Sem estes trabalhos, não seria possível verificar que os vereadores da Câmara Municipal de Curitiba apresentam características particulares de ação política, relacionadas à área de atuação e à geografia dos votos. Pode-se inferir destes dados a produção de requerimentos e sua distribuição nas bases eleitorais.

Sem dúvida os trabalhos acadêmicos constituem grande fonte de recursos para a análise do legislativo municipal.

O que queremos avançar é no sentido de apontar para a configuração da atividade parlamentar não nos seus particularismos, isto é, a análise da produção de requerimentos como definidor da prática legislativa, ou a condecoração de elementos da sociedade civil como perfumaria. Não pactuamos com a visão de d'Ávila $\mathrm{F}^{\mathrm{o}}$ de que se trata de analisar "uma espécie de lata de lixo da atividade legislativa para observar as táticas, as representações em uso do jogo político local, por intermédio da interação ordinária de detentores de recursos de autoridade com demandantes de toda ordem de benefícios públicos.” (d'Ávila Fo , Lima \& Jorge, 2011). Com esta visão, não conseguiremos enxergar o poder legislativo em todas as suas inter-relações, e essa dificuldade faz com que estas inter-relações sejam vistas apenas como "conexões eleitorais" (p.189), e não como pretendemos conceituar, como “conexões representativas".

As atividades legislativas levadas a cabo pelos vereadores, portanto, devem ser vistas como diferentes faces da representação política, no sentido de múltiplas possibilidades de relacionamento com a população (e não apenas com os eleitores) e o poder executivo. Se um vereador obteve 50\% ou mais de votos em uma determinada região e passa a solicitar benefícios para estes bairros, se esses se concretizam, são beneficiados não apenas os seus eleitores, mas toda a comunidade a que pertencem.

Como vimos na extensa lista de atividades de diversos conteúdos apresentada pelos vereadores, podemos ter certeza de uma coisa: alguns vereadores priorizam sua ação no recebimento de pedidos pontuais de eleitores ou da população e, a partir deles, apresentam requerimentos de solicitação ao executivo; outros dão mais importância ao debate e à colocação de questões de interesse social e econômico, na apresentação de projetos de lei e na discussão de posições partidárias ou ideológicas. Também as homenagens trazem benefícios mútuos de reconhecimento simbólico.

O que queremos evidenciar é que nenhum parlamentar deixa de participar ou agir em nenhuma destas instâncias. Todas fazem parte da representação político-parlamentar e não podem de maneira alguma serem negligenciadas em qualquer investigação científica, sob pena de perda da configuração da identidade representativa, construída pelos componentes da conexão político-representativa. 


\section{Conclusão}

As variadas atividades legislativas levadas a cabo pelos vereadores devem ser vistas como diferentes faces da representação política, no sentido de múltiplas possibilidades de relacionamento com a população (e não apenas com os eleitores) e o poder executivo (mas não somente este poder, já que, como vimos a representação se faz em várias instâncias).

A atividade legislativa exercida pelos vereadores na Câmara deve ser compreendida em sua extensão e complexidade, se considerarmos as interfaces de atuação entre os vereadores e desses junto aos eleitores e aos outros poderes públicos, visto que, ao compartimentar essa atuação, dando mais ênfase a um a outro aspecto, perde-se a compreensão da trajetória político-representativa e conferese supremacia à trajetória eleitoral ou eleitoreira no trabalho de vereança.

A análise do conteúdo das Emendas Orçamentárias Aditivas e dos Requerimentos a outros órgãos e à Prefeitura permitiu compreender as demandas trazidas à Câmara, delinear um mapeamento dos seus autores, considerando os bairros a que pertencem e inferir sobre as deficiências do Poder Executivo. Se uma mesma demanda é apropriada por vereadores de diferentes partidos, se mantém como demanda durante todo o mandato e segue não respondida, após realizadas as eleições, sinalizase que há um descompasso entre o exercício do direito de voto e a fruição de uma cidadania plena, que envolve viver na cidade, usufruindo igualmente dos recursos destinados aos serviços públicos.

Em nosso trabalho, pretendemos colaborar com a discussão sobre o legislativo municipal, delineando as ações parlamentares mais cotidianas como forma de desvelar as diferentes estratégias de aproximação com a população e dos outros poderes públicos, com a clara intenção de se tornarem os mediadores necessários à resolução de demandas não resolvidas pelo poder executivo.

Pretendemos mostrar também que há um baixo grau de eficácia nesta estratégia, visto que o poder executivo monopoliza grande parte dos recursos materiais e financeiros que possibilitam a resolução dos problemas que se apresentam para a população do município.

Nessa investigação, mereceram destaque as duas características que mostram o predomínio do Poder Executivo sobre a condução das políticas públicas e a gestão estatal, a saber: por um lado a exclusividade constitucional do Poder Executivo sobre matéria orçamentária e de organização da administração pública aliada à necessária agilidade na resolução de problemas impostos pela vida coletiva; por outro a difícil compreensão dos mecanismos da democracia representativa, como a tramitação de projetos de lei e o conjunto de regras institucionais deste modo de representação política. Teremos então como visível um molde de gestão em que há o predomínio absoluto de leis criadas pelo Executivo e uma aparente passividade e inoperância do Legislativo, ou ainda, mais reatividade do que proatividade. 
Torna-se necessário, então, a criação de outros laços com o eleitorado, dentro dos limites institucionais que definem os tipos de troca que se estabelecem. Fazer projetos de lei, enviar requerimentos com solicitações aos órgãos públicos, sugerir ações específicas e apresentar emendas ao orçamento são medidas que são engendradas como forma de manter os laços com os representados, cada uma delas necessária como complementação das outras. Todos os vereadores em algum momento do mandato utilizam uma das possibilidades de ação parlamentar para desenvolver a conexão político-representativa. Mais do que isso, vemos que se desenvolve um tipo de inter-relação que ultrapassa a intenção eleitoral, e torna-se fator de sobrevivência enquanto poder. Os diferentes modos de atuação dos parlamentares, possibilitados por um desenho institucional organizado exatamente para esse fim, cria uma simbiose necessária a ambas as partes da troca.

O trabalho legislativo desencadeia um "saber fazer", constituindo-se, parte em aprendizado criativo, parte em repetição das práticas que se conhecem ao longo de um mandato. A composição de uma bancada para atuação na Câmara, coloca em intercessão diferentes percursos de formação, diferentes projetos político-ideológicos e representantes com diferentes potenciais para o exercício do mandato. Considerar a Câmara como o cenário em que formas de protagonismo político tomam lugar e investigar como as performances dos vereadores afirmam ou negam a defesa do modelo de democracia representativa, permanece como desafio para futuros estudos. Em outros termos, identificar as limitações do trabalho legislativo, pode significar maior esclarecimento sobre a potencialidade desse trabalho e seu valor para a sociedade.

Para que o planejamento urbano de nossa cidade deixe de fazer prevalecer a retórica da valorização do trabalho administrativo técnico sobre o político de apelo social, constante nas diversas gestões desde a década de 80, há a exigência de intervenções organizadas e ações mais duradouras e autônomas que revelam seus limites ao não terem um braço institucional a impulsioná-las e torná-las efetivas. Ao parlamento, no meu entendimento, cabe este papel, se dentro de suas prerrogativas se propuser a buscar a capacidade de liderança que hoje não tem na busca de processos deliberativos ampliados na construção de uma democracia substantiva.

\section{Referências Bibliográficas}

ANASTASIA, F. "Transformando o Legislativo: a experiência da Assembleia Legislativa de Minas Gerais". In: SANTOS, F. (Org.). O Poder Legislativo nos Estados: diversidade e convergência. Rio de Janeiro: Editora FGV, 2001.

AURÉLIO, D. P. (Org.) Representação política-textos clássicos Lisboa: Livros Horizonte, 2009. 
AVRITZER, L. Cultura política, atores sociais e democratização - Uma Crítica às Teorias da Transição Para a Democracia. Disponível em: <http://www.anpocs.org.br/portal/publicacoes/rbcs_00_28/rbcs28_09.htm>. Acesso em: 02/05/2017.

AVRITZER, L. \& COSTA, S. "Teoria crítica, Democracia e Esfera Pública: concepções e usos na América Latina “. DADOS - Revista de Ciências Sociais, Rio de Janeiro, v. 47, n. 4, p. 703-728.

BARBOSA, E. M. \& KOSICKI, E. M. Judicialização da Política e Controle Judicial de Políticas Públicas. Disponível em: 〈http://www.scielo.br/pdf/rdgv/v8n1/v8n1a03> . Acesso em: 02/05/2017.

BERNARDI, J. L. O Poder Familiar na Câmara Municipal de Curitiba (1947 a 2014) - Programa de Pós-graduação em Sociologia/UFPR - 2014.

BORBA, J. "Cultura Política, ideologia e comportamento eleitoral: alguns apontamentos teóricos sobre o caso brasileiro”. Opinião Pública, Campinas, v. XI, nº 1, mar. 2005, p. 147-168.

BOURDIEU, P. Coisas Ditas. São Paulo: Brasiliense, 1983b.

. Pierre Bourdieu: sociologia / organizador [da coletânea] Renato Ortiz. Tradução de Paula Montero e Alícia Auzmendi. - São Paulo: Ática, 1983c.

Questões de Sociologia. Rio de Janeiro: Marco Zero, 1983d.

BURITY, J. A. Identidade e Cidadania: A Cultura Cívica no Contexto de Uma Nova Relação Entre Sociedade Civil, Indivíduos e Estado. Disponível em: <http://www.clacso.org/wwwclacso/espanol/html/biblioteca/sala/sala2.html\#br>. Acesso em: $02 / 05 / 2017$.

CABRAL, D. Regimento das Câmaras Municipais - Memória da Administração Pública Brasileira. Disponível em: <http://linux.an.gov.br/mapa/?p=5751>. Acesso em: 05/05/2017.

CASTRO, H. "Cultura Política: a tentativa de construção de um conceito adequado à América Latina”. Revista de Estudos e Pesquisas sobre as Américas, v. 2, n. 1, jan./jun. 2008.

CERVI, E. \& COLOMBO, R. Quem manda no voto em Curitiba? uma análise do desempenho eleitoral dos candidatos à prefeitura da cidade em 2012. Disponível em: <http://www.blogempublico.com/wpcontent/uploads/2013/11/2013_ArtigoEleicaoCtba_EmersonRenan.pdf >. Acesso em: 05/05/2017.

CLÈVE, M. C. - Atividade Legislativa do Poder Executivo no Estado contemporâneo e na Constituição de 1988/. 3. ed. São Paulo: Editora dos Tribunais, 1993.

COSTA, S. "Movimentos sociais, democratização e a construção de esferas públicas locais".

Revista Brasileira de Ciências Sociais. v. 12, n. 35, 1992. Disponível em: $<$ http://www.scielo.br/scielo.php?script=sci_arttext\&pid=S010269091997000300008\&lng=pt\&nrm $=$ iso $>$.ISSN 0102-6909. http://dx.doi.org/10.1590/S0102-69091997000300008>. Acesso em: 05/05/2017>. Acesso em: 02/05/2017. 
COUTO, C. G.; ABRUCIO, L. F. "Governando a cidade? A força e a fraqueza da Câmara Municipal." São Paulo em Perspectiva, São Paulo, v. 9, n. 2, p. 57-65, 1995. Disponível em: http://produtos.seade.gov.br/produtos/spp/v09n02/v09n02_09.pdf >. Acesso em: 05/06/2017.

DAHL, R. Sobre a Democracia. Robert A. Dahl: tradução de Beatriz Sidou. - Brasília: Editora Universidade de Brasília, 2001.

D'ÁVILA Fo , JORGE V. \& COELHO A. A política cotidiana dos Vereadores e as relações entre Executivo e Legislativo em âmbito municipal: o caso do município de Araruama. Disponível em: <http://www.scielo.br/pdf/rsocp/n22/n22a12>. Acesso em: 2008.

Produção legislativa na Câmara Municipal do Rio de Janeiro: indicações, representação política e intermediação de interesses. Disponível em: <http://desigualdadediversidade.soc.pucrio.br/media/14\%20DeDespecial\%20Art\%2010\%20\%20Paulo.pdf>. Acesso em: 05/05/2017.

Disponível

Acesso ao Poder, Participação e Troca Política: Orçamento e disputa política municipal.

<http://portal.anpocs.org/portal/index.php?option=com_docman\&task=doc_view\&gid=4088\&Itemi d=319 > . Acesso em: 02/05/2017.

O Clientelismo e o exercício de poder no Brasil. Disponível em: http://base.d-ph.info/pt/fiches/dph/fiche-dph-8518.html >. Acesso em: 05/05/2017.

FAGUNDES, B. F. L. "Matrizes do Pensamento Culturalista: Tocqueville e Almond-Verba". Lua Nova, São Paulo, n. 74, 2008, p.131-150.

FEMIA, J. Dicionário do Pensamento Social do séc. XX - Rio de janeiro - Zahar - 1993 - verbete "cultura política" p. 170-171

FERREIRA, A. Dinâmica Político-Eleitoral em São Luís (1982-1992). Disponível em: 〈http://www.cienciapolitica.org.br/wp-content/uploads/2014/04/28_6_2012_20_10_55.pdf>. Acesso: 05/05/2017.

FIGUEIREDO \& LIMONGI Incentivos Eleitorais, Partidos e Política Orçamentária. Dados, Vol. 45, $\mathrm{n}^{\circ} 2$ Rio de Janeiro, 2002

FIGUEIREDO, A. C. \& LIMONGI, F. (2004) "Modelos de Legislativo: o Legislativo brasileiro em perspectiva comparada." Plenarium, ano 1, n.1, novembro, pp. 41-56

FIGUEIREDO, A. C.; LIMONGI, F. Executivo e Legislativo na nova ordem constitucional. Rio de Janeiro: FGV, 1999.

GEERTZ, C. A interpretação das culturas. Rio de Janeiro: LTC, 2008. p.13-41.

HORTA, R. M. "Poder Legislativo e monopólio da lei no mundo contemporâneo". Revista de Informação Legislativa, ano 31, n 123, p. 149-158, 1994.

KUSCHNIR, K. Política e mediação cultural: um estudo da Câmara Municipal do Rio de Janeiro. Rio de Janeiro. Dissertação (Mestrado em Antropologia Social). Universidade Federal do Rio de Janeiro, Rio de Janeiro, 1993. 
LOPEZ, F. G. "A política cotidiana dos vereadores e as relações entre Executivo e Legislativo em âmbito municipal: o caso do município de Araruama”. Revista de Sociologia e Política, n.22, jun. 2004, p.153-177.

LOUREIRO, M. R. "Interpretações contemporâneas da representação”. Revista Brasileira de Ciência Política, Brasília, n. 1. Brasília, jan. /jun. 2009, p. 63-93. Disponível em: <http://www.plataformademocratica.org/Publicacoes/19692_Cached.pdf >. Acesso em: 05/06/2017.

O Vereador e a câmara municipal, O - 4.ed. / [coordenação de] Marcos Flávio R. Gonçalves; [coordenação editorial de] Sandra Mager. - Rio de Janeiro: IBAM, 2014.

MAURANO, A. O poder legislativo municipal. Dissertação (Mestrado em Direito Político e Econômico) - Universidade Presbiteriana Mackenzie, São Paulo, 2007.

MORAES, F. Executivo e Legislativo no Brasil pós-Constituinte. São Paulo Perspec. 2001, vol.15, n.4, 2001, p. 45-52. Disponível em: <<http://www.scielo.br/scielo.php?script=sci_arttext\&pid=S0102-

88392001000400006\&lng=en\&nrm=iso > . Acesso em: 05/05/2017.

MORAIS, T. F. Neoinstitucionalismo e o sistema político brasileiro. Disponível em: <www.cchla.ufrn.br/humanidades/trabGT.php?opcao=32>. Acessado em: 01/09/2011.

MOURÃO, P. \& CUNHA D. "Políticas Pork Barrel: Um estudo sobre o caso português do PIDDAC". Revista Econômica, Rio de Janeiro, v. 13, n 1, jun. 2011. Disponível em: <http://www.proppi.uff.br/revistaeconomica/sites/default/files/Politicas>. Acesso em: 05/05/2017.

NAZARENO, L. R. "Política local e a ocupação de cargos eletivos em Curitiba (1985-2000)". In: CODATO, Adriano Nervo; SANTOS, Fernando José dos. (Orgs.). Partidos e eleições no Paraná: uma abordagem histórica. Curitiba - PR: Tribunal Regional Eleitoral do Paraná (TRE-PR), 2006.

NUNES, J. de C. Do Estado Federado e sua organização municipal. 2. ed. Brasília: Câmara dos Deputados, 1982.

OLIVEIRA, D. de Curitiba e o mito da cidade modelo. Curitiba: Ed. da UFPR, 2000.

OLIVEIRA, R. C. de - Na teia do nepotismo. Curitiba, Insight, 2012.

PANKE, L. \& CERVI. E. (Orgs.). Eleições nas capitais brasileiras em 2012: um estudo sobre o HGPE em disputas municipais. Independente. Curitiba: Pós-graduação em Comunicação e Pósgraduação em Ciência Política. UFPR, 2013. 